\title{
Case management for dementia in primary health care: a systematic mixed studies review based on the diffusion of innovation model
}

This article was published in the following Dove Press journal:

Clinical Interventions in Aging

II June 2014

Number of times this article has been viewed

\section{Vladimir Khanassov \\ Isabelle Vedel \\ Pierre Pluye}

Department of Family Medicine, McGill University, Montreal, QC, Canada
Correspondence: Isabelle Vedel Department of Family Medicine, McGill University, 5858 Côte-des-Neiges, Third Floor, Suite 300, Montreal, Quebec, H3S IZI

Tel +I 5 I43408222

Email isabelle.vedel@mcgill.ca
Background: The purpose of this study was to examine factors associated with the implementation of case management $(\mathrm{CM})$ interventions in primary health care (PHC) and to develop strategies to enhance its adoption by PHC practices.

Methods: This study was designed as a systematic mixed studies review (including quantitative and qualitative studies) with synthesis based on the diffusion of innovation model. A literature search was performed using MEDLINE, PsycInfo, EMBASE, and the Cochrane Database (1995 to August 2012) to identify quantitative (randomized controlled and nonrandomized) and qualitative studies describing the conditions limiting and facilitating successful CM implementation in PHC. The methodological quality of each included study was assessed using the validated Mixed Methods Appraisal Tool.

Results: Twenty-three studies (eleven quantitative and 12 qualitative) were included. The characteristics of CM that negatively influence implementation are low CM intensity (eg, infrequent follow-up), large caseload (more than 60 patients per full-time case manager), and approach, ie, reactive rather than proactive. Case managers need specific skills to perform their role (eg, good communication skills) and their responsibilities in PHC need to be clearly delineated.

Conclusion: Our systematic review supports a better understanding of factors that can explain inconsistent evidence with regard to the outcomes of dementia CM in PHC. Lastly, strategies are proposed to enhance implementation of dementia CM in PHC.

Keywords: systematic mixed studies review, dementia, case management, primary health care, implementation, diffusion of innovation

\section{Introduction}

Dementia is the most common age-related neurodegenerative disorder. ${ }^{1}$ There are approximately 500,000 people living with dementia in Canada, and over the next 40 years this number will increase by 2.5 -fold. ${ }^{2}$ Dementia is the fourth most common cause of death among patients aged 75 years and over worldwide, the second most burdensome of all brain diseases in Western Europe, and number five among the top ten burdensome diseases in Europe in terms of years of life lost and years living with a disability. ${ }^{3}$

This vulnerable population is characterized by complex needs that require a comprehensive approach by health care professionals. ${ }^{4}$ Fragmentation and inefficiency of health services represent major problems for these patients. ${ }^{5,6}$ As the hub of services, primary health care (PHC) and, in particular, primary care physicians (PCPs), have been internationally recognized as well positioned to serve as these 
patients' first contact with the health care system for early diagnosis and management of dementia. ${ }^{7}$ However, PHC is not yet fully prepared to deal with the diverse needs of these patients. ${ }^{5,6}$

To address these challenges, case management (CM) has been designed to increase the capacity of PHC to cope with this population, improve the quality of dementia care, and develop cost-effective and efficient ways to coordinate services. ${ }^{8}$ The Case Management Society of America defines $\mathrm{CM}$ as "a collaborative process of assessment, planning, facilitation, care coordination and advocacy for options and services to meet an individual's and family's comprehensive health needs through communication and available resources to promote quality cost-effective outcomes". ${ }^{8}$ Over the past few decades, several $\mathrm{CM}$ demonstration projects have been implemented in PHC to improve clinical outcomes for patients with dementia and to optimize resource utilization, but the research evidence on their outcomes is inconsistent. ${ }^{9-12}$ It has been shown that barriers to implementation hinder outcomes. ${ }^{13}$ Callahan et al demonstrated that dementia CM in PHC is unlikely to be successful unless adequate attention is paid to barriers to implementation. ${ }^{14}$ At this writing, there is no systematic review of the conditions limiting and facilitating successful dementia CM implementation. Thus, our research objectives were to examine the factors associated with the implementation of CM interventions in PHC and develop strategies to enhance its adoption in $\mathrm{PHC}$ practices.

\section{Materials and methods}

To address our objectives, we conducted a systematic mixed studies review, including studies with diverse designs, including quantitative and qualitative methods ${ }^{15}$ Including different forms of evidence produces findings that are more relevant to decision-makers, ${ }^{16}$ overcomes the issue of a partial portrait based on examining one type of research in isolation, ${ }^{17}$ and assists the critical analysis of implementation processes from the viewpoint of the targeted participants. ${ }^{15}$

\section{Data sources}

The review was based on a systematic, comprehensive search of four databases (MEDLINE, PsycInfo, EMBASE, and the Cochrane Database of Systematic Reviews) according to the Preferred Reporting Items for Systematic Reviews and Meta-Analyses (PRISMA) statement. ${ }^{18}$ Articles published between 1995 (official publication of the Standards of Practice for Case Management) ${ }^{8}$ and August 31, 2012 were considered for inclusion. The literature search was conducted by a specialized librarian. See Supplementary material for a detailed example of our search in PsycInfo.

\section{Inclusion criteria}

1. CM interventions comprising all the components identified by the Case Management Society of America (case finding and screening, assessment, care planning, implementation and management, monitoring, and review) ${ }^{8}$ for patients of any age and sex with cognitive impairment or dementia (any type) residing in the community and/or their informal caregivers and receiving $\mathrm{CM}$ provided by health care professionals in a range of community settings (eg, patients' homes, physicians' offices). ${ }^{19}$

2. Quantitative (eg, randomized controlled trials) and qualitative (eg, case studies) studies describing the conditions limiting and facilitating successful $\mathrm{CM}$ implementation.

3. Participants were patients, caregivers, PHC health care professionals (PCPs, case managers, such as nurses and/ or social workers, or geriatricians, neurologists, and psychiatrists).

4. Language of publication was English or French.

\section{Study selection process}

Based on the inclusion criteria, two reviewers (VK, IV) independently examined the records (titles and abstracts) obtained from the databases. VK and IV then independently examined full-text copies of the studies corresponding to the selected records. At each step, differences in coding (inclusion/exclusion of a record) were resolved by consensus or referred to a third reviewer (PP). Kappa scores were calculated to estimate interreviewer reliability. ${ }^{20}$ If more than one publication described the same study, they were treated as one study. All companion articles were also searched.

\section{Data extraction}

Information was extracted from each study by two researchers working independently (VK, IV), and comprised author, publication date, region, study design, methodology, methods of data collection and analysis, participant characteristics, sample size, diagnosis, and conditions limiting and facilitating successful CM implementation. Differences arising from the data extraction were resolved by consensus.

\section{Synthesis}

In order to describe the conditions limiting and facilitating successful implementation and assemble a broad knowledge 
base from studies with diverse methodologies and methods, we used a narrative synthesis approach. ${ }^{15}$ This method "relies primarily on the use of words and text to summarize and explain the findings of the synthesis". ${ }^{15}$ First, the narrative data (key sentences eliciting barrier-related and enablerrelated research results and researchers' interpretations of these results) were extracted from all the articles in the sample. These data were analyzed following standard methods for qualitative thematic analysis in order to identify key themes associated with CM implementation. ${ }^{21,22}$

Second, to better understand the conditions of CM implementation we used a recent modification of the diffusion of innovation model as an organizing framework because it fitted better with our objectives. ${ }^{23,24}$ This model pertains to addressing the predicament of how to disseminate and sustain interventions in health service delivery and identifying domains in which key factors influence intervention uptake and implementation. It consists of eight interrelated components: the attributes of the innovation (eg, relative advantage, namely clear benefits over existing health care services), the concerns of potential adopters (eg, properties and potential benefits), communication and influence (eg, interpersonal influence), organizational antecedents to innovation (eg, capacity to absorb new knowledge), readiness for innovation (eg, innovation-system fit), the implementation process (eg, human resource issues), linkage (eg, communication within the organization), and the broader context (eg, specific incentives at the national level).

\section{Quality assessment}

As recommended by PRISMA, ${ }^{18}$ the methodological quality of the included studies was assessed independently by two reviewers (VK, PP). We used the Mixed Methods Appraisal Tool, which has been designed and validated for the critical appraisal of studies with diverse designs. ${ }^{25}$ The tool demonstrated good reliability, with the consistency of the global quality score between reviewers (intraclass correlation) being 0.72 before and 0.94 after discussion. ${ }^{25}$ The Mixed Methods Appraisal Tool takes into consideration all reported outcomes (primary and secondary). This tool has four criteria for the evaluation of each study design (0 to 4 ). Thus, to calculate an interrater reliability for several criteria, the weighted kappa calculation is required. ${ }^{26}$ Studies of lower quality (with a score of 0 or 1 ) were not excluded from the synthesis, because our primary objective was to gain knowledge on dementia CM and highlight the main limiting and facilitating conditions that will need to be addressed in future research.

\section{Results}

The search yielded 12,746 records (Figure 1). Of these, 12,238 records were not eligible based on the title or abstract (kappa 0.79), and 490 were eliminated based on the fulltext publications (kappa 0.91). Twenty-three studies were included in the review (31 publications).

\section{Characteristics of the selected studies}

Of the included studies, eleven were quantitative studies, comprising nine randomized controlled trials, ${ }^{10-12,27-39}$ one nonrandomized study, ${ }^{40}$ and one quantitative descriptive study $^{41}$ (Table 1), and 12 were qualitative studies, comprising eleven qualitative descriptive studies ${ }^{42-53}$ and one multiplecase study ${ }^{54}$ (Table 2). Ten studies were conducted in the USA, ${ }^{10,12,27,36,39,40,43,45,48,50}$ five in the UK, ${ }^{42,46,47,49,51}$ and four in the Netherlands. ${ }^{32,41,52,54}$ The remaining four studies were from Belgium, ${ }^{31}$ Australia, ${ }^{53}$ India, ${ }^{34}$ and People's Republic of China. ${ }^{35,55}$ All articles were published in English.

\section{Conditions limiting and facilitating successful CM implementation}

The key conditions for implementation are presented in Table 3 .

\section{Conditions limiting and facilitating successful CM implementation and proposed strategies for optimal implementation}

Table 4 presents the correspondences between conditions limiting and facilitating successful dementia CM implementation and the components of the diffusion of innovation model. ${ }^{24}$

\section{Attributes of CM as an innovation}

There are two characteristics of CM interventions that can play important roles in the implementation process, ie, intensity of CM (and more specifically, size of the caseload) and inclusion criteria.

\section{Intensity of CM and caseload}

Low intensity (eg, large caseload, infrequent follow-up, low fidelity, partial completion of the designed intervention) was associated with an absence of outcomes for the patientcaregiver dyad. ${ }^{31,35,36,41}$ A large caseload was considered the factor that changed the proactive nature of dementia care (aimed at preventing a crisis) toward a more reactive approach (dealing with crises). ${ }^{43,44,54}$ An average caseload of 


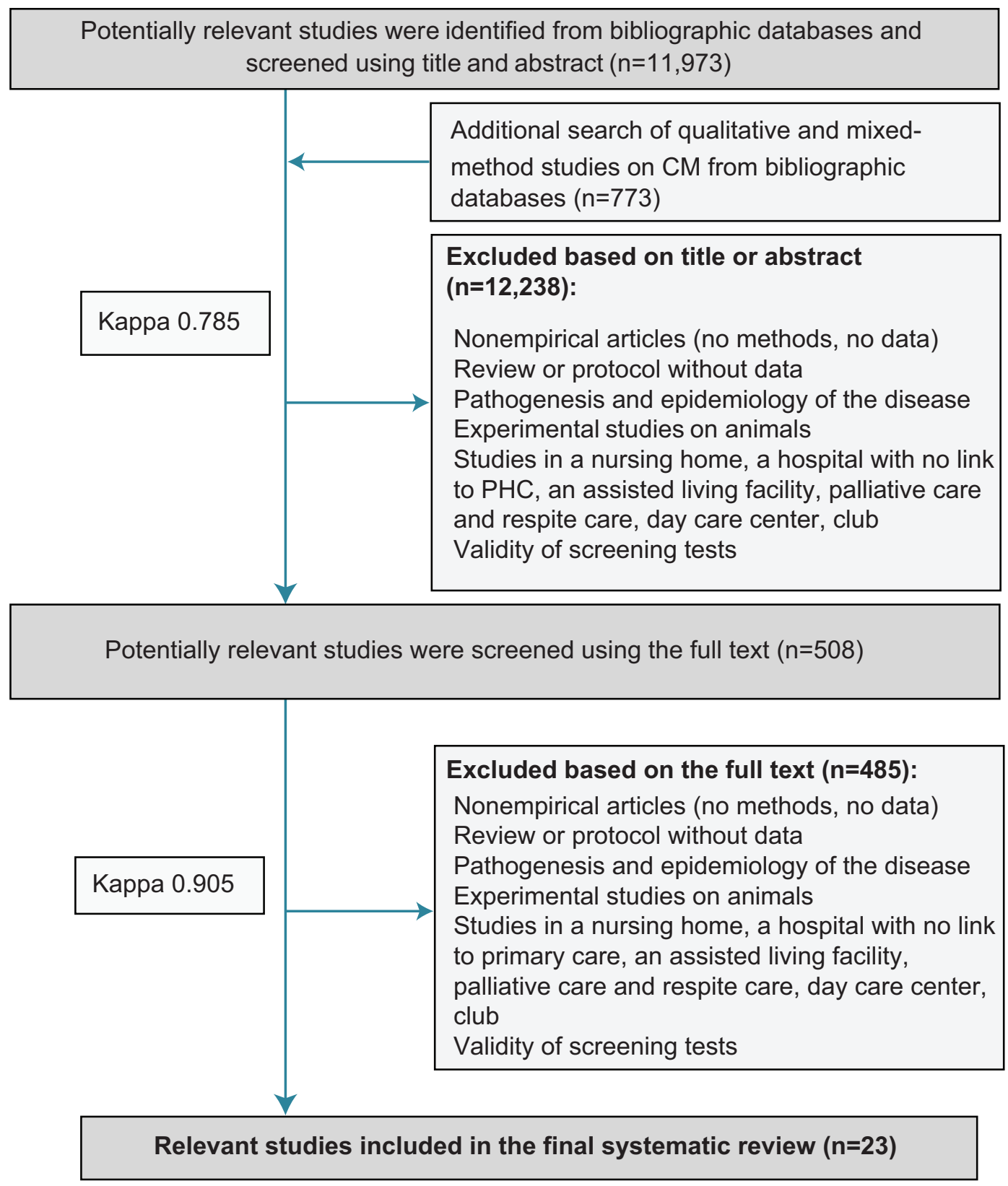

Figure I PRISMA flow chart.

Abbreviations: CM, case management; PHC, primary health care; PRISMA, Preferred Reporting Items for Systematic Reviews and Meta-Analyses.

50-60 patient-caregiver dyads per full-time case manager was perceived as optimal. ${ }^{43,44,54}$

\section{Inclusion criteria by target population}

Case managers considered inclusion of patients with a confirmed diagnosis but without prominent dementia symptoms (early stage of dementia) as a limiting factor toward achieving desired outcomes. ${ }^{27,31,50,54}$ Recruitment of patients based on diagnosis tends to include participants who will not benefit from $\mathrm{CM}$ due to the absence of substantial risk (patients in the early stage of the disease).${ }^{31}$ Referral of patients with a problem, regardless of diagnosis and age, was viewed as more beneficial for patients. ${ }^{50}$

\section{Concerns of potential adopters}

In line with the model, the adoption of a CM intervention is a process that is influenced by a negative attitude on the part of health care professionals, case managers, and patientcaregiver dyads toward CM.

Health care professionals expressed doubts over the value of CM within the current health care system. ${ }^{43,44,47-52,54}$ Health care professionals and members of steering committees 
Table I Characteristics of quantitative studies

\begin{tabular}{|c|c|c|c|c|c|}
\hline Reference & $\begin{array}{l}\text { Design of } \\
\text { study }\end{array}$ & $\begin{array}{l}\text { Population } \\
\text { studied }\end{array}$ & $\begin{array}{l}\text { Sample } \\
\text { size }\end{array}$ & Characteristics of intervention & $\begin{array}{l}\text { Health care team } \\
\text { composition }\end{array}$ \\
\hline $\begin{array}{l}\text { Newcomer et al,"' } \\
\text { Miller et } \mathrm{al}^{29} \\
\text { (USA) }\end{array}$ & $\mathrm{RCT}$ & Dementia & 8,095 & $\begin{array}{l}\text { Assistance with support service; } \\
\text { psychological support of caregivers }\end{array}$ & $\begin{array}{l}\text { Case manager (nurse, social } \\
\text { worker, mental health worker, } \\
\text { gerontology worker) }\end{array}$ \\
\hline $\begin{array}{l}\text { Fortinsky et } \mathrm{al}^{12} \\
\text { (USA) }\end{array}$ & RCT & Dementia & 84 & $\begin{array}{l}\text { Education of caregivers; regular follow-up } \\
\text { of patients; action plan for caregivers }\end{array}$ & $\begin{array}{l}\text { Case manager (social worker) } \\
\text { working with PCP on care plan }\end{array}$ \\
\hline $\begin{array}{l}\text { Schoenmakers et } \mathrm{al}^{31} \\
\text { (Belgium) }\end{array}$ & $\mathrm{RCT}$ & $\begin{array}{l}\text { Cognitive } \\
\text { impairment }\end{array}$ & 62 & $\begin{array}{l}\text { Guidance of the family carer in organizing } \\
\text { home care; regular follow-up (home visit, } \\
\text { phone calls) }\end{array}$ & $\begin{array}{l}\text { Primary care professional with } \\
\text { a bachelor degree working } \\
\text { directly with PCP }\end{array}$ \\
\hline $\begin{array}{l}\text { Jansen et } \mathrm{al}^{29,30} \\
\text { (the Netherlands) }\end{array}$ & RCT & $\begin{array}{l}\text { Cognitive } \\
\text { impairment }\end{array}$ & 99 & $\begin{array}{l}\text { In-home assessment; developed care plan } \\
\text { for patient and caregiver with problem } \\
\text { identification; liaison to support service; } \\
\text { referrals to health professionals if needed }\end{array}$ & $\begin{array}{l}\text { Case manager (nurse } \\
\text { specialized in geriatric care) } \\
\text { working directly with PCP }\end{array}$ \\
\hline $\begin{array}{l}\text { Dias et } \mathrm{al}^{31} \\
\text { (India) }\end{array}$ & $\mathrm{RCT}$ & Dementia & 81 & $\begin{array}{l}\text { Education of caregivers about the } \\
\text { disease; emotional support for caregivers; } \\
\text { improvement of caregivers' skills; referral to } \\
\text { support groups; care plan development based } \\
\text { on an agreed protocol, its implementation, } \\
\text { and regular follow-up }\end{array}$ & $\begin{array}{l}\text { Case manager (no social } \\
\text { work or medical background) } \\
\text { working in collaboration with } \\
\text { psychiatrist }\end{array}$ \\
\hline $\begin{array}{l}\text { Lam et al }{ }^{32} \\
\text { (People's Republic } \\
\text { of China) }\end{array}$ & $\mathrm{RCT}$ & Dementia & 102 & $\begin{array}{l}\text { In-home assessment; home-based program of } \\
\text { cognitive stimulation; assistance with support } \\
\text { service registration }\end{array}$ & $\begin{array}{l}\text { Case manager (occupational } \\
\text { therapist) }\end{array}$ \\
\hline $\begin{array}{l}\text { Mittelman et } \mathrm{al}^{33-35} \\
\text { (USA) }\end{array}$ & $\mathrm{RCT}$ & Dementia & 406 & $\begin{array}{l}\text { Baseline assessment; individual and family } \\
\text { counselling sessions tailored to each } \\
\text { caregiver's situation; care plan development } \\
\text { (management of troublesome behavior, } \\
\text { communication techniques), its regular } \\
\text { reassessment and ad hoc telephone } \\
\text { counseling; ongoing emotional support } \\
\text { and education }\end{array}$ & Case manager (social worker) \\
\hline $\begin{array}{l}\text { Wright et } \mathrm{al}^{36} \\
\text { (USA) }\end{array}$ & $\mathrm{RCT}$ & Dementia & 93 & $\begin{array}{l}\text { Problem identification and care plan } \\
\text { development; regular medication revision; } \\
\text { caregiver support program; assistance with } \\
\text { support service }\end{array}$ & Case manager (nurse) \\
\hline $\begin{array}{l}\text { Vickrey et al } \\
\text { (USA) }\end{array}$ & RCT & Dementia & 408 & $\begin{array}{l}\text { In-home assessment; problem list } \\
\text { development with development of a } \\
\text { plan, including for the caregiver; regular } \\
\text { reassessment; liaison to support services; } \\
\text { monitoring and communication via } \\
\text { Web-based system }\end{array}$ & $\begin{array}{l}\text { Case manager (social worker) } \\
\text { working with PCP on care plan }\end{array}$ \\
\hline $\begin{array}{l}\text { Cherry et } \mathrm{al}^{37} \\
\text { (USA) }\end{array}$ & $\begin{array}{l}\text { Nonrandomized } \\
\text { study }\end{array}$ & Dementia & 83 & $\begin{array}{l}\text { Comprehensive geriatric assessment; regular } \\
\text { follow-ups; assessment of adequacy of family } \\
\text { support; development of treatment plan; } \\
\text { assistance with support service through } \\
\text { referrals; education of caregiver-patient dyads }\end{array}$ & Case manager (social worker) \\
\hline $\begin{array}{l}\text { Verkade et } \mathrm{al}^{38} \\
\text { (the Netherlands) }\end{array}$ & Survey & - & $\begin{array}{l}30 \\
\text { experts } \\
\text { in } \mathrm{CM}\end{array}$ & - & - \\
\hline
\end{tabular}

Abbreviations: CM, case management; PCP, primary care physicians; RCT, randomized controlled trial.

expressed great uncertainty and reluctance over the capacity of CM to improve services for elderly persons. ${ }^{43,50,51}$ Confusion about the case manager's role accounted for the limitations of the interventions, especially at the beginning of $\mathrm{CM}$ implementation. ${ }^{41,43,44,50,51}$ Despite the fact that health care professionals, especially PCPs (43\%), believed that patient care could be improved with the addition of a dementiatrained care coordinator, their reluctance to integrate the CM model persisted. ${ }^{31}$ Netting et al reported that it took one year before physicians recognized the case manager's contributions to the care of patients, such as mobilization of resources, focus on psychosocial aspects of the patient's life, 
Table 2 Characteristics of qualitative studies

\begin{tabular}{|c|c|c|c|}
\hline Reference & Design of study & Sample & Characteristics of intervention \\
\hline $\begin{array}{l}\text { Adams et } \mathrm{al}^{42} \\
\text { (UK) }\end{array}$ & $\begin{array}{l}\text { Qualitative descriptive/thematic } \\
\text { analysis }\end{array}$ & I4 case managers & $\begin{array}{l}\text { CM focused on dementia patients } \\
\text { and their caregivers }\end{array}$ \\
\hline $\begin{array}{l}\text { Black et } \mathrm{al}^{40,41} \\
\text { (USA) }\end{array}$ & $\begin{array}{l}\text { Qualitative descriptive/thematic } \\
\text { analysis }\end{array}$ & 27 community-based case managers & $\begin{array}{l}\text { CM focused on the diseases of older } \\
\text { persons, including dementia; focus on } \\
\text { advanced care planning skills of case } \\
\text { managers as a part of their functions }\end{array}$ \\
\hline $\begin{array}{l}\text { Bogardus et } \mathrm{al}^{42} \\
\text { (USA) }\end{array}$ & $\begin{array}{l}\text { Qualitative descriptive/constant } \\
\text { comparative method }\end{array}$ & $\begin{array}{l}\text { Ten sets of participants (each set: } \\
\text { patient, caregiver, case manager, } \\
\text { clinician) }\end{array}$ & $\begin{array}{l}\text { CM focused on dementia patients } \\
\text { and their caregivers }\end{array}$ \\
\hline $\begin{array}{l}\text { Gibson et } \mathrm{al}^{43} \\
\text { (UK) }\end{array}$ & $\begin{array}{l}\text { Qualitative descriptive/thematic } \\
\text { analysis }\end{array}$ & $\begin{array}{l}\text { Ten dyads (patient with mild to } \\
\text { moderate dementia and caregiver) } \\
\text { receiving service either from a } \\
\text { hospital-based memory clinic or a } \\
\text { community-based nursing service }\end{array}$ & $\begin{array}{l}\text { Comparison of a community-based } \\
\text { and a clinic-based memory service }\end{array}$ \\
\hline $\begin{array}{l}\text { Gladman et } \mathrm{al}^{44} \\
\text { (UK) }\end{array}$ & $\begin{array}{l}\text { Qualitative descriptive/thematic } \\
\text { analysis with conceptual } \\
\text { mapping }\end{array}$ & $\begin{array}{l}\text { Six PCPs, one geriatric psychiatrist, } \\
\text { caregivers, patient advocate, team } \\
\text { manager, representatives of Alzheimer } \\
\text { Association }\end{array}$ & $\begin{array}{l}\text { CM focused on dementia patients } \\
\text { and their caregivers }\end{array}$ \\
\hline $\begin{array}{l}\text { Liebel et } \mathrm{al}^{45} \\
\text { (USA) }\end{array}$ & $\begin{array}{l}\text { Qualitative descriptive/thematic } \\
\text { analysis }\end{array}$ & 19 patients & $\begin{array}{l}\text { Secondary analysis of Medicare primary and } \\
\text { consumer-directed care; demonstration } \\
\text { designed for patients with disabilities, } \\
\text { including cognitive impairment }(68 \%)\end{array}$ \\
\hline $\begin{array}{l}\text { McCrae et al }{ }^{46} \\
(\mathrm{UK})\end{array}$ & $\begin{array}{l}\text { Convergent design/thematic } \\
\text { analysis }\end{array}$ & $\begin{array}{l}33 \text { and } 27 \text { health care professionals } \\
\text { (nurses, occupational therapist, } \\
\text { psychiatrists, psychologist, support } \\
\text { workers, team leaders) at } 6 \text { and } \\
24 \text { months, respectively }\end{array}$ & $\begin{array}{l}\text { Evaluation of "Improving the Quality of } \\
\text { Care for Older People in Lambeth" impact } \\
\text { from staff perspectives: did it help or hinder } \\
\text { them in performing their roles? }\end{array}$ \\
\hline $\begin{array}{l}\text { Netting et } \mathrm{al}^{47} \\
\text { (USA) }\end{array}$ & $\begin{array}{l}\text { Qualitative descriptive/thematic } \\
\text { analysis }\end{array}$ & $\begin{array}{l}36 \text { different participants in CM: } \\
\text { physicians, case managers, case assistants, } \\
\text { practice managers, office staff }\end{array}$ & $\begin{array}{l}\mathrm{CM} \text { focused on the diseases of older } \\
\text { persons, including dementia }\end{array}$ \\
\hline $\begin{array}{l}\text { Seddon et } \mathrm{al}^{48} \\
\text { (UK) }\end{array}$ & $\begin{array}{l}\text { Qualitative descriptive/latent } \\
\text { content analysis }\end{array}$ & 8 care managers and 64 caregivers & $\begin{array}{l}\text { CM focused on caregiver's assessment } \\
\text { (ability to care and continue care, coping } \\
\text { ability, relationship with a care recipient) }\end{array}$ \\
\hline $\begin{array}{l}\text { Van Eijken et al }{ }^{49} \\
\text { (the Netherlands) }\end{array}$ & $\begin{array}{l}\text { Qualitative descriptive/inductive } \\
\text { thematic analysis }\end{array}$ & $\begin{array}{l}\text { I5 PCPs, } 6 \text { case managers (nurses), } \\
2 \text { geriatricians, II patients and } \\
37 \text { caregivers }\end{array}$ & $\begin{array}{l}\text { CM focused on problems with cognition, } \\
\text { mood, behavior, functional decline, } \\
\text { mobility, nutrition and urinary incontinence }\end{array}$ \\
\hline $\begin{array}{l}\text { Waugh et } \mathrm{al}^{50} \\
\text { (Australia) }\end{array}$ & $\begin{array}{l}\text { Qualitative descriptive/thematic } \\
\text { analysis }\end{array}$ & $\begin{array}{l}\text { Five staff workers of the Mercy } \\
\text { Community Care agency: } 2 \text { managers, } \\
2 \text { case managers, one outreach worker }\end{array}$ & CM for dementia patients living alone \\
\hline $\begin{array}{l}\text { Minkman et } \mathrm{al}^{51} \\
\text { (the Netherlands) }\end{array}$ & $\begin{array}{l}\text { Multiple case study/thematic } \\
\text { analysis }\end{array}$ & 9 case managers & $\begin{array}{l}\text { CM focused on dementia patients and their } \\
\text { caregivers }\end{array}$ \\
\hline
\end{tabular}

Abbreviations: $\mathrm{CM}$, case management; $\mathrm{PCP}$, primary care physicians.

extension of the physician in terms of preventive care, and a reduction in time spent in patient consultations. ${ }^{50}$

Case managers also contributed to this situation..$^{31,32,42,51}$ For example, only $63 \%$ of case managers clearly explained their role to the patient-caregiver dyads and $25 \%$ did not give any detail during the assessment. ${ }^{51}$ Not surprisingly, negative attitudes on the part of case managers towards $\mathrm{CM}$ prevented patients and caregivers from receiving care as it had been initially designed.$^{32}$ When case managers did not recognize the importance of their role, ${ }^{42}$ or misinterpreted it, this led them to resist collaborating. ${ }^{31}$ In such conditions, health care professionals and patients-caregiver dyads expressed doubt about the helpfulness of the CM intervention. ${ }^{30,32}$

\section{Communication and influence}

Individual adoption depends on communication between health care professionals, case managers and patientcaregiver dyads and their interpersonal influence. One of the factors associated with $\mathrm{CM}$ implementation was insufficient collaboration between local health care professionals (eg, general practitioner, geriatrician, and case manager, ie, nurse or social worker). ${ }^{41,43,45-48,50,51,54}$ For example, $52 \%$ of 


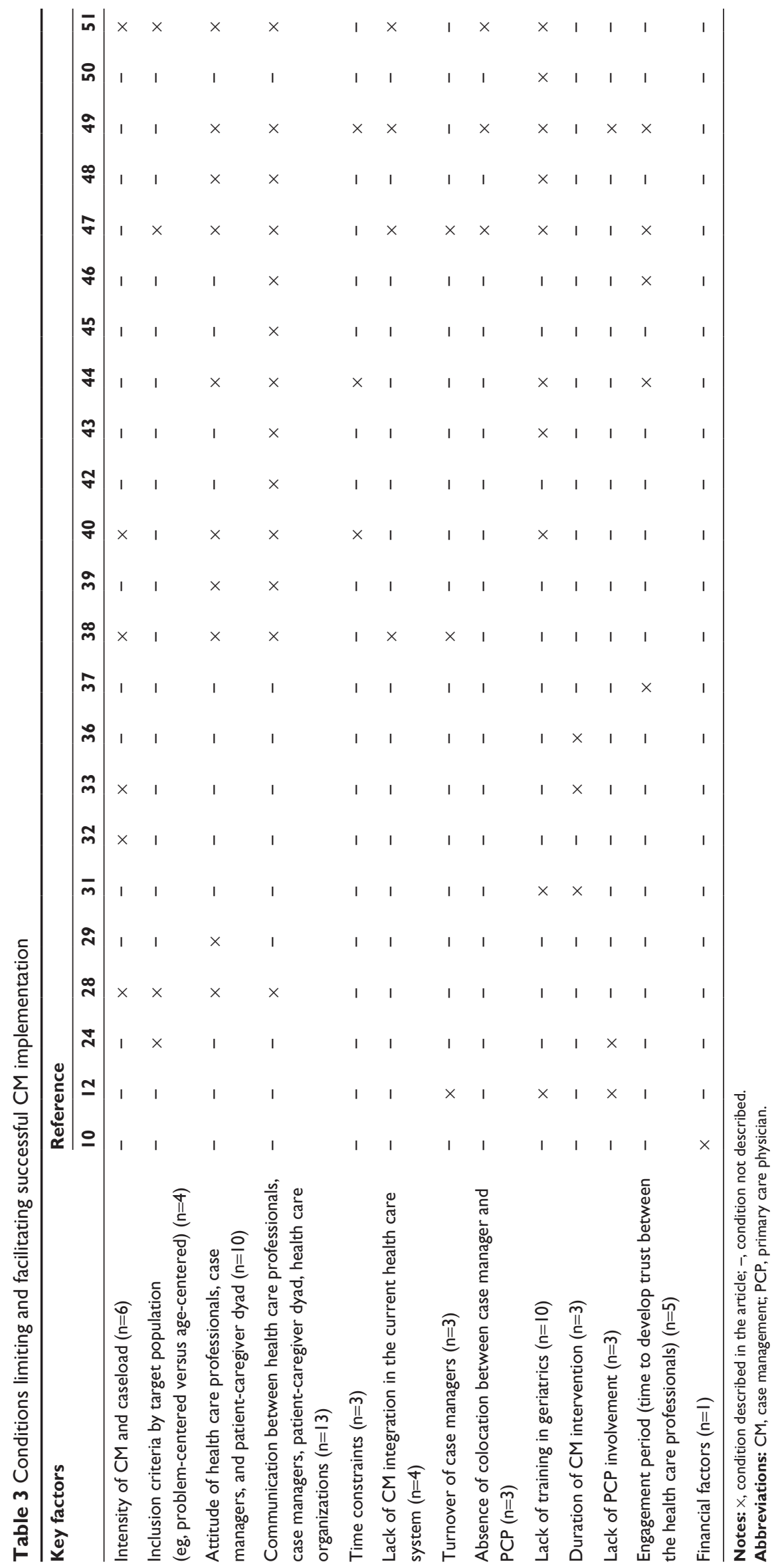


Table 4 Matrix of key limiting and facilitating conditions, components of the diffusion of innovation model, and strategies

\begin{tabular}{|c|c|c|}
\hline $\begin{array}{l}\text { Components of } \\
\text { Greenhalgh model }\end{array}$ & $\begin{array}{l}\text { Key limiting and facilitating } \\
\text { conditions }\end{array}$ & Strategies to be used to enhance implementation \\
\hline \multirow[t]{2}{*}{$\begin{array}{l}\text { Attributes of } \mathrm{CM} \text { as } \\
\text { an innovation }\end{array}$} & Intensity of CM and size of caseload & $\begin{array}{l}\text { High intensity of CM } \\
\text { Optimal caseload (50-60 patients per full-time case manager) }\end{array}$ \\
\hline & Inclusion criteria & $\begin{array}{l}\text { Use of patient-oriented approach rather than age/diagnosis-oriented } \\
\text { strategy }\end{array}$ \\
\hline $\begin{array}{l}\text { Concerns of potential } \\
\text { adopters }\end{array}$ & $\begin{array}{l}\text { Negative attitudes of health care } \\
\text { professionals, case managers, and } \\
\text { patient-caregiver dyads toward CM }\end{array}$ & $\begin{array}{l}\text { Information campaign about the value of CM targeting health care } \\
\text { professionals involved in dementia health care } \\
\text { Regular feedback to tailor the intervention to the needs of health care } \\
\text { professionals and the context of the health care facility } \\
\text { Regular contact with health care professionals to promote the role of case } \\
\text { manager }\end{array}$ \\
\hline $\begin{array}{l}\text { Communication and } \\
\text { influence }\end{array}$ & $\begin{array}{l}\text { Communication between health care } \\
\text { professionals, case managers, and } \\
\text { patient-caregiver dyads }\end{array}$ & $\begin{array}{l}\text { Clear delineation of the responsibilities of the health care professionals } \\
\text { involved in CM (eg, interdisciplinary care protocol) } \\
\text { Regular meetings of case managers with interdisciplinary team and PCPs } \\
\text { Internet-based care management software system for care planning and } \\
\text { coordination } \\
\text { Web-based access to electronic health records }\end{array}$ \\
\hline $\begin{array}{l}\text { Organizational antecedents } \\
\text { for innovation }\end{array}$ & Interorganizational communication & $\begin{array}{l}\text { Clear system of communication (eg, referral system) } \\
\text { Specific guidelines for referral to support services (eg, Alzheimer } \\
\text { Association) }\end{array}$ \\
\hline \multirow[t]{2}{*}{$\begin{array}{l}\text { Organizational readiness } \\
\text { for innovation }\end{array}$} & Time constraints & $\begin{array}{l}\text { Definition of priorities in the provision of care (simple cases versus more } \\
\text { complicated conditions) } \\
\text { Sharing of tasks between PCPs and case managers }\end{array}$ \\
\hline & $\begin{array}{l}\text { Lack of CM integration into current } \\
\text { health care system }\end{array}$ & Integration of CM in the primary health care facility \\
\hline \multirow[t]{4}{*}{ Implementation process } & Turnover of case managers & $\begin{array}{l}\text { Appointment of case managers with experience and good communication } \\
\text { qualities } \\
\text { Training in communication for case managers } \\
\text { Individual and team training for staff members }\end{array}$ \\
\hline & $\begin{array}{l}\text { Absence of colocation between case } \\
\text { manager and PCP }\end{array}$ & Location of the case manager in the same facility as PCPs \\
\hline & Lack of training in geriatrics & $\begin{array}{l}\text { Educational training (eg, facilitated sessions and decision-support software } \\
\text { to improve diagnosis of dementia) } \\
\text { Use of dementia treatment guidelines designed for PHC }\end{array}$ \\
\hline & Duration of intervention & At least 12 months of intervention before evaluating the outcomes \\
\hline \multirow[t]{2}{*}{ Linkage } & $\begin{array}{l}\text { Lack of PCP involvement or } \\
\text { reluctance of PCPs to be involved in } \\
\text { care of patients with dementia }\end{array}$ & $\begin{array}{l}\text { Information campaign targeting PCPs about the value of CM (champion) } \\
\text { Training (eg, facilitated sessions and decision-support software to improve } \\
\text { diagnosis of dementia) }\end{array}$ \\
\hline & Engagement period & At least 6 months of engagement to develop confidence in the intervention \\
\hline Broader context & Financial factors & Capitation-based or mixed remuneration \\
\hline
\end{tabular}

Abbreviations: CM, case management; PCP, primary care physician; PHC, health care.

case managers indicated that poor communication with health care professionals negatively affected their work. ${ }^{43,44}$ Case managers had to initiate the first contact, and viewed personal contact as a precondition for effective communication. ${ }^{52}$ Establishing communication ("learning to interact") was perceived as time-consuming and required the development of a sensitive strategy tailored to each practice setting's own culture. ${ }^{50}$

While trusting relationships between the patient-caregiver dyad and the case manager were considered a prerequisite for achievement of long-term objectives, poor communication between them was also reported..$^{31,41,48}$ For instance, only $38 \%$ of caregivers reported being able to talk about their needs and concerns with the case manager, and only $42 \%$ felt that their concerns were understood. ${ }^{51}$

\section{Organizational antecedents to innovation}

According to the model, ${ }^{24}$ different degrees of innovation adoption by organizations (more or less innovative) may be due to a lack of interorganizational communication. Our results suggest that a close working relationship and permeability of the boundaries between health care 
services were seen as necessary for support and efficiency of intervention. ${ }^{41,42,49}$

\section{Organizational readiness for innovation}

Our results indicate that an organization may be unprepared to adopt $\mathrm{CM}$ due to the time constraints that health care professionals face and poor $\mathrm{CM}$ integration into the current health care system.

\section{Time constraints}

Pressures on their time prevented case managers from fulfilling their tasks completely (eg, caregiver's assessment). ${ }^{43,44,47}$ A similar issue was highlighted for PCPs. ${ }^{52}$ Case managers believed that more time spent by the PCP on the patient's problem would facilitate its solution. ${ }^{52}$

\section{Lack of CM integration in current health care system} While experts stated that $\mathrm{CM}$ is impossible unless it is fully integrated into the health care chain, ${ }^{41}$ case managers were not considered "part of" physicians' practices. ${ }^{50}$ Lack of $\mathrm{CM}$ integration into the team in the existing health care system impeded reinforcement and assurance of continuity of dementia care..$^{52,54}$

\section{Implementation process}

Critical factors that could affect the adoption of $\mathrm{CM}$ were case manager turnover, lack of colocation of case manager and PCP, lack of training in geriatrics, and short duration of intervention.

\section{Turnover of case managers}

Turnover of case managers was a source of dissatisfaction with $\mathrm{CM} .{ }^{12}$ Indeed, a sufficient amount of time is needed to establish good relationships between a patient-caregiver dyad and a case manager. ${ }^{12,41,50}$ This leads to the development of emotional ties that facilitate provision of effective service.

\section{Absence of colocation of case manager and PCP}

Absence of case manager colocation in the health care facility (especially in $\mathrm{PHC}$ ) was seen as preventing full integration of CM into the existing health care practice..$^{50,52,54}$

\section{Lack of training in geriatrics}

The complexity of the work requires that case managers have a range of qualities, such as specific knowledge of dementia and other geriatric conditions, analytical ability (eg, the ability to distinguish the symptoms of dementia from normal aging), a patient-centered as opposed to health care facility-oriented approach, an ability to deliver proactive instead of reactive care, a good awareness of local services, and an understanding of welfare and human rights, suicide risk, and compliance with medications. ${ }^{34,43,44,46,47,51,52,54}$

Similar issues were reported by PCPs..$^{50,52,54}$ Absence of the training required to make the diagnosis was a concern for PCPs, especially regarding patients with multiple health problems. ${ }^{50,52,53}$ PCPs viewed recognizing and evaluating cognitive deficiency as the most challenging task (along with dealing with mood and mobility problems). ${ }^{52}$ Insufficient knowledge of geriatric diagnostic tools and their use in routine primary care practice were listed as another limiting factor. ${ }^{52}$ In addition, PCPs showed a lack of initiative or were uncertain about how to counsel (eg, only $30 \%$ of them discussed the care plan with a caregiver) ${ }^{12}$ and were reluctant to prescribe antidementia medications. ${ }^{34}$

\section{Duration of intervention}

Short duration of the intervention seems to be a limiting factor. ${ }^{34,36-39}$ Dias et al acknowledged that the short follow-up period precluded them from achieving the expected effect. ${ }^{34}$ Wright et al also indicated that a 12-month period is insufficient to reveal program outcomes: it was solely toward the end of the study (at 12 months) that trends were observed in terms of decreased behavioral symptoms, caregivers recovering from depression, and better health. ${ }^{39}$

\section{Linkage}

CM is more likely to be adopted when the PCPs involved in dementia care and other health care professionals have sufficient time to develop confidence in CM (the "engagement period").

\section{Lack of involvement of PCP in dementia care}

Little or no involvement on the part of PCPs in the care of patients with dementia was perceived as a disadvantage, since PCPs provide support during the early stages of the disease. ${ }^{52}$ Also, noninvolvement by a patient's PCP in the intervention has been seen as a limiting factor. ${ }^{27}$ For instance, an attempt by the Alzheimer Association to collaborate closely with PHC practice resulted in only $30 \%$ PCP involvement. ${ }^{12}$

\section{Engagement period}

Confidence in the intervention grew among health care professionals over the first year of implementation. .0,47,49,50,52 $^{2}$ During the first year, PCPs, case managers, patients, and caregivers developed trusting and working relationships (the "engagement period"). This engagement period is crucial 
Table 5 MMAT quality appraisal for studies with diverse designs

\begin{tabular}{|c|c|c|c|c|c|}
\hline \multirow[t]{2}{*}{ Reference } & \multicolumn{5}{|l|}{ Quality appraisal } \\
\hline & Randomization & Blinding & Outcome data & Dropout rate & Overal \\
\hline \multicolumn{6}{|l|}{ RCTs } \\
\hline 10 & I & I & I & 0 & 3 \\
\hline 12 & 0 & I & I & 0 & 2 \\
\hline 24 & 0 & 0 & I & 1 & 2 \\
\hline 28 & I & I & 0 & I & 3 \\
\hline 29 & I & I & I & 1 & 4 \\
\hline 31 & 1 & 0 & I & 0 & 2 \\
\hline 32 & I & I & I & I & 4 \\
\hline 33 & 1 & I & I & 1 & 4 \\
\hline 36 & 0 & 0 & 0 & 0 & 0 \\
\hline Reference & Sampling strategy & Representativeness & $\begin{array}{l}\text { Appropriate } \\
\text { measurements }\end{array}$ & Response rate & Overall \\
\hline 38 & 1 & 1 & 1 & 1 & 4 \\
\hline \multicolumn{6}{|c|}{ Nonrandomized study } \\
\hline Reference & Selection bias & $\begin{array}{l}\text { Appropriate } \\
\text { measurements }\end{array}$ & Compared groups & Outcome data & Overall \\
\hline 37 & 0 & 0 & I & I & 2 \\
\hline \multicolumn{6}{|c|}{ Quantitative descriptive (survey) } \\
\hline 38 & 1 & I & I & 1 & 4 \\
\hline Reference & Source of data & Methods of analysis & Context & Reflexivity & Overall \\
\hline \multicolumn{6}{|c|}{ Qualitative studies } \\
\hline 39 & I & I & 0 & 1 & 3 \\
\hline 40 & 1 & I & 0 & 0 & 2 \\
\hline 42 & I & I & 0 & 0 & 2 \\
\hline 43 & I & I & I & 0 & 3 \\
\hline 44 & 1 & I & 1 & 1 & 4 \\
\hline 45 & 1 & 1 & 0 & 0 & 2 \\
\hline 46 & 1 & 0 & I & 0 & 2 \\
\hline 47 & 1 & I & I & 0 & 3 \\
\hline 48 & 1 & I & 0 & 0 & 2 \\
\hline 49 & I & I & 0 & 0 & 2 \\
\hline 50 & 1 & 0 & 0 & 0 & I \\
\hline 51 & 1 & I & 0 & 0 & 2 \\
\hline
\end{tabular}

Notes: I, criterion met; 0 , criterion not met or unable to determine.

Abbreviations: MMAT, Mixed Methods Appraisal Tool; RCTs, randomized controlled trials.

because it leads to improved results in the second year of the intervention. ${ }^{40,49,50}$

\section{Broader context}

In line with the model, $\mathrm{CM}$ is more likely to be successful when there are financial incentives and mandates at the national level. ${ }^{24}$ The adoption and sustainability of $\mathrm{CM}$ depends on staff remuneration. Vickrey et al have suggested that fee-for-service remuneration can limit adoption of CM. ${ }^{10}$ In contrast, capitation under Medicare-managed care is more likely to favor CM becoming the "usual" practice. ${ }^{10}$

\section{Quality of evidence from the selected studies}

The quality of each of the 23 studies was assessed based on Mixed Methods Appraisal Tool criteria. ${ }^{25}$ Overall, the included studies were of moderate quality (69.6\%); only two $(8.6 \%)$ were of lower quality (score 0 or 1$)$, while five $(22 \%)$ were of higher quality (all criteria met, Table 5). Two studies were rated as being of lower quality due to unclear descriptions of randomization, allocation concealment, complete outcome data, and rate of dropout, ${ }^{39}$ the methodology used in data analysis, the relationship of the findings to the context, and the reflexivity of the researchers. ${ }^{53}$

\section{Discussion}

This paper reports on the first systematic review to have examined the conditions limiting and facilitating successful implementation of $\mathrm{CM}$ interventions designed for patients with dementia and their caregivers in PHC, and proposed strategies for successful adoption of CM based on the diffusion of innovation model. 
As CM is intended to provide individualized care to patients through a one-to-one approach, ${ }^{56}$ the intensity of $\mathrm{CM}$ should reflect the needs of patients. ${ }^{57}$ Caseload is an important component of $\mathrm{CM}$ intensity. ${ }^{57}$ If the caseload is too large, there is the risk of a shift from proactive care (eg, prevention of a health crisis, of avoidable utilization of resources, or of premature deterioration of functional ability) toward a reactive approach (eg, dealing with acute care episodes, crisis management). ${ }^{58}$ Limiting the average caseload seems to be beneficial for frail elderly patients, ${ }^{57}$ with a load of 50-60 patients per full-time case manager being suggested ${ }^{57}$ or $12-15$ patients per 8 hours of work. ${ }^{41}$ However, the load depends on the patients' demand for care, the amount of activities (CM intensity), and the timing of $\mathrm{CM}$ commencement (stage of the disease). ${ }^{41}$

Another important factor to consider is the target population. There is an ongoing debate about the usefulness (or lack thereof) of CM for all stages of dementia. ${ }^{59}$ A patientcentered approach as opposed to one based on age/disease inclusion criteria seems to be better, as it allows provision of proactive care to patients at a higher risk for a major problem (eg, a behavioral problem) or at a later stage of dementia. ${ }^{59}$ Jansen et al found no benefit from CM for patients with modest symptoms of dementia behavioral problems..$^{32}$ Thus, it seems that patients at the early stage of dementia do not benefit from $\mathrm{CM}$.

Another major factor is to have a clearly defined role for case managers. Clear delineation of responsibilities among $\mathrm{CM}$ health care professionals, especially the PCP and the case manager, will help PCPs have more time for patients with more complicated chronic conditions. ${ }^{52} \mathrm{~A}$ clear interdisciplinary care protocol may be one solution for delegating certain tasks to case managers (eg, cognitive screening) in a CM intervention. ${ }^{9}$

Finally, the characteristics of case managers play a role in the success of CM. Stable human resources are necessary for a sustained and successful implementation. ${ }^{24}$ Fixsen et al considered staff selection as one of the core components of an implementation. ${ }^{60}$ Effective $\mathrm{CM}$ requires individuals with good communication and collaboration skills. ${ }^{61,62}$

\section{Strengths and limitations of the systematic review}

We systematically identified studies relevant to implementation of dementia CM in PHC, appraised the quality of included studies using a validated tool designed for a systematic mixed studies review, and synthesized the findings with a narrative approach. Moreover, we used an organizing framework to propose key implementation strategies. Our search strategy was comprehensive. However, like any review, our findings are limited by the amount of available research evidence.

\section{Conclusion}

Our systematic review contributes to a better understanding of the reasons for inconsistent efficacy of dementia CM in PHC. We identified key conditions limiting and facilitating successful CM implementation and key strategies for enhancing the adoption of CM in PHC. In particular, these are optimal caseload (less than 60 patients per full-time case manager), target population (patients with prominent symptoms of dementia), and delineation of the case manager's role and their characteristics (an interdisciplinary care protocol). Thus, this review can be used to guide the implementation of dementia CM. Further research is needed to test our implementation strategies in a PHC clinical environment.

\section{Acknowledgments}

We thank Muriel Gueriton (specialized librarian) for literature search. This study was funded by the Canadian Institute of Health Research (grant reference KRS 119799). The first author (VK) was supported by the Fonds de Recherche du Québec-Santé as a Master's student.

\section{Disclosure}

The authors report no conflicts of interest in this work.

\section{References}

1. Alzheimer's Association. Alzheimer's disease facts and figures. 2013 Available from: http://www.alz.org/downloads/facts_figures_2013.pdf. Accessed May 15, 2014.

2. Alzheimer Society of Canada. Rising tide: the impact of dementia on Canadian society. 2010. Available from: http://www.alzheimer.ca/ / media/Files/national/Advocacy/ASC_Rising\%20Tide-Executive\%20 Summary_Eng.pdf. Accessed May 15, 2014.

3. Institute of Medicine. Living Well with Chronic Illness: A Call for Public Health Action. Washington, DC, USA: The National Academies Press; 2012.

4. Knopman D, Donohue J, Gutterman E. Patterns of care in the early stages of Alzheimer's disease: impediments to timely diagnosis. J Am Geriatr Soc. 2000;48(3):300-304.

5. Pimlott NJ, Persaud M, Drummond N, et al. Family physicians and dementia in Canada: Part 1. Clinical practice guidelines: awareness, attitudes, and opinions. Can Fam Physician. 2009;55(5):506-507.e1-e5.

6. Aminzadeh F, Molnar FJ, Dalziel WB, Ayotte D. A review of barriers and enablers to diagnosis and management of persons with dementia in primary care. Can Geriatr J. 2012;15(3):85-94.

7. World Health Organization, 2012. Dementia: a public health priority. Available from: http://whqlibdoc.who.int/publications/2012/9789241564458_ eng.pdf. Accessed May 15, 2014.

8. Case Management Society of America, 2012. Available from: http:// www.cmsa.org. Accessed May 15, 2014. 
9. Callahan C, Boustani M, Unverzagt F, et al. Effectiveness of collaborative care for older adults with Alzheimer disease in primary care: a randomized controlled trial. JAMA. 2006;295(18):2148-2157.

10. Vickrey B, Mittman B, Connor K, et al. The effect of a disease management intervention on quality and outcomes of dementia care: a randomized, controlled trial. Ann Intern Med. 2006;145(10):713-726.

11. Newcomer R, Miller R, Clay T, Fox P. Effects of the Medicare Alzheimer's disease demonstration on Medicare expenditures. Health Care Financ Rev. 1999;20(4):45-65.

12. Fortinsky RH, Kulldorff M, Kleppinger A, Kenyon-Pesce L. Dementia care consultation for family caregivers: collaborative model linking an Alzheimer's association chapter with primary care physicians. Aging Ment Health. 2009;13(2):162-170.

13. Grol RP, Bosch MC, Hulscher ME, Eccles MP, Wensing M. Planning and studying improvement in patient care: the use of theoretical perspectives. Milbank Q. 2007;85(1):93-138.

14. Callahan $\mathrm{C}$, Boustani M, Weiner M, et al. Implementing dementia care models in primary care settings: The Aging Brain Care Medical Home. Aging Ment Health. 2011;15(1):5-12.

15. Popay J. Moving Beyond Effectiveness in Evidence Synthesis: Methodological Issues in the Synthesis of Diverse Sources of Evidence. London, UK: National Institute for Health and Clinical Excellence; 2006.

16. Harden A. Mixed-Methods Systematic Reviews: Integrating Quantitative and Qualitative Findings. National Center for the Dissemination of Disability Research (NCDDR), Department of Education's Office of Special Education and Rehabilitative Services (OSERS); 2010. Available from: http://www.ktdrr.org/ktlibrary/articles_pubs/ncddrwork/ focus/focus25/Focus25.pdf. Accessed May 15, 2014.

17. Thomas J, Harden A, Oakley A, et al. Integrating qualitative research with trials in systematic reviews. BMJ. 2004;328(7446):1010-1012.

18. Moher D, Liberati A, Tetzlaff J, Altman DG. Preferred reporting items for systematic reviews and meta-analyses: the PRISMA statement. Ann Intern Med. 2009;151(4):264-269, W64.

19. Canadian Institutes of Health Research. Community-based primary health care, 2014. Available from: http:/www.cihr.ca/e/43626.html. Accessed May 15, 2014.

20. Gwet KL. Computing inter-rater reliability and its variance in the presence of high agreement. Br J Math Stat Psychol. 2008;61 Pt 1:29-48.

21. Overhage JM, Perkins S, Tierney WM, McDonald CJ. Controlled trial of direct physician order entry: effects on physicians' time utilization in ambulatory primary care internal medicine practices. J Am Med Inform Assoc. 2001;8(4):361-371.

22. Casalino L, Gillies RR, Shortell SM, et al. External incentives, information technology, and organized processes to improve health care quality for patients with chronic diseases. JAMA. 2003;289(4):434-441.

23. Greenhalgh T, Stramer K, Bratan T, Byrne E, Mohammad Y, Russell J. Introduction of shared electronic records: multi-site case study using diffusion of innovation theory. BMJ. 2008;337:a1786.

24. Greenhalgh T, Robert G, MacFarlane F, Bate P, Kyriakidou O. Diffusion of innovations in service organizations: systematic review and recommendations. Milbank Q. 2004;82(4):581-629.

25. Pace R, Pluye P, Bartlett G, et al. Testing the reliability and efficiency of the pilot Mixed Methods Appraisal Tool (MMAT) for systematic mixed studies review. Int J Nurs Stud. 2012;49(1):47-53.

26. Cohen J. A power primer. Psychol Bull. 1992;112(1):155-159.

27. Newcomer R, Spitalny M, Fox P, Yordi C. Effects of the Medicare Alzheimer's Disease Demonstration on the use of community-based services. Health Serv Res. 1999;34(3):645-667.

28. Fox P, Newcomer R, Yordi C, Arnsberger P. Lessons learned from the Medicare Alzheimer Disease Demonstration. Alzheimer Dis Assoc Disord. 2000;14(2):87-93.

29. Miller R, Newcomer R, Fox P. Effects of the Medicare Alzheimer's Disease Demonstration on nursing home entry. Health Serv Res. 1999;34(3):691-714.

30. Yordi C, DuNah R, Bostrom A, Fox P, Wilkinson A, Newcomer R. Caregiver supports: outcomes from the Medicare Alzheimer's disease demonstration. Health Care Financ Rev. 1997;19(2):97-117.
31. Schoenmakers B, Buntinx F, Delepeleire J. Supporting family carers of community-dwelling elder with cognitive decline: a randomized controlled trial. Int J Family Med. 2010;2010:184152.

32. Jansen AP, van Hout HP, Nijpels G, et al. Effectiveness of case management among older adults with early symptoms of dementia and their primary informal caregivers: a randomized clinical trial. Int J Nurs Stud. 2011;48(8):933-943.

33. Jansen AP, van Hout HP, van Marwijk HW, et al. (Cost)-effectiveness of case-management by district nurses among primary informal caregivers of older adults with dementia symptoms and the older adults who receive informal care: design of a randomized controlled trial [ISCRTN83135728]. BMC Public Health. 2005;5:133.

34. Dias A, Dewey ME, D'Souza J, et al. The effectiveness of a home care program for supporting caregivers of persons with dementia in developing countries: a randomised controlled trial from Goa, India. PLoS One. 2008;3(6):e2333.

35. Lam LC, Lee JS, Chung JC, Lau A, Woo J, Kwok TC. A randomized controlled trial to examine the effectiveness of case management model for community dwelling older persons with mild dementia in Hong Kong. Int J Geriatr Psychiatry. 2010;25(4):395-402.

36. Mittelman MS, Roth DL, Haley WE, Zarit SH. Effects of a caregiver intervention on negative caregiver appraisals of behavior problems in patients with Alzheimer's disease: results of a randomized trial. J Gerontol B Psychol Sci Soc Sci. 2004;59(1):P27-P34.

37. Mittelman MS, Haley WE, Clay OJ, Roth DL. Improving caregiver well-being delays nursing home placement of patients with Alzheimer disease. Neurology. 2006;67(9):1592-1599.

38. Mittelman MS, Roth DL, Coon DW, Haley WE. Sustained benefit of supportive intervention for depressive symptoms in caregivers of patients with Alzheimer's disease. Am J Psychiatry. 2004;161(5): $850-856$.

39. Wright L, Litaker M, Laraia M, DeAndrade S. Continuum of care for Alzheimer's disease: a nurse education and counseling program. Issues Ment Health Nurs. 2001;22(3):231-252.

40. Cherry D, Vickrey B, Schwankovsky L, Heck E, Plauchm M, Yep R. Interventions to improve quality of care: the Kaiser PermanenteAlzheimer's Association Dementia Care Project. Am J Manag Care. 2004;10(8):553-560

41. Verkade P, van Meijel B, Brink C, van Os-Medendorp H, Koekkoek B, Francke A. Delphi research exploring essential components and preconditions for case management in people with dementia. BMC Geriatr. 2010;10:54.

42. Adams T. A descriptive study of the work of community psychiatric nurses with elderly demented people. J Adv Nurs. 1996;23(6):1177-1184

43. Black K, Fauske J. Exploring influences on community-based case managers' advance care planning practices: facilitators or barriers? Home Health Care Serv Q. 2007;26(2):41-58.

44. Black K, Fauske J. Measuring case managers' advance care planning practice: translating focus group findings to survey development. Care Manag J. 2008;9(4):166-176.

45. Bogardus ST Jr, Bradley EH, Tinetti ME. A taxonomy for goal setting in the care of persons with dementia. J Gen Intern Med. 1998;13(10): $675-680$.

46. Gibson G, Timlin A, Curran S, Wattis J. The impact of location on satisfaction with dementia services amongst people with dementia and their informal carers: a comparative evaluation of a community-based and a clinic-based memory service. Int Psychogeriatr. 2007;19(2): 267-277.

47. Gladman JR, Jones RG, Radford K, Walker E, Rothera I. Person-centred dementia services are feasible, but can they be sustained? Age Ageing. 2007;36(2):171-176.

48. Liebel DV, Powers BA, Friedman B, Watson NM. Barriers and facilitators to optimize function and prevent disability worsening: a content analysis of a nurse home visit intervention. J Adv Nurs. 2012;68(1): 80-93.

49. McCrae N, Banerjee S. Modernizing mental health services for older people: a case study. Int Psychogeriatr. 2011;23(1):10-19. 
50. Netting F, Williams F. Implementing a case management program designed to enhance primary care physician practice with older persons. J Appl Gerontol. 1998;18(1):25-45.

51. Seddon D, Robinson CA. Carers of older people with dementia: assessment and the Carers Act. Health Soc Care Community. 2001;9(3): 151-158.

52. van Eijken M, Melis R, Wensing M, Rikkert MO, van Achterberg T. Feasibility of a new community-based geriatric intervention programme: an exploration of experiences of GPs, nurses, geriatricians, patients and caregivers. Disabil Rehabil. 2008;30(9):696-708.

53. Waugh $\mathrm{F}$. Where does risk feature in community care practice with older people with dementia who live alone? Dementia. 2009;8(2):205-222.

54. Minkman MM, Ligthart SA, Huijsman R. Integrated dementia care in The Netherlands: a multiple case study of case management programmes. Health Soc Care Community. 2009;17(5):485-494.

55. Chien W, Lee I. Randomized controlled trial of a dementia care programme for families of home-resided older people with dementia. J Adv Nurs. 2011;67(4):774-787.

56. Global Action Against Dementia. G8 Dementia Summit Declaration Available from: https://www.gov.uk/government/uploads/system/ uploads/attachment_data/file/265869/2901668_G8_DementiaSummitDeclaration_acc.pdf. Accessed May 15, 2014.
57. Pacala JT, Boult C, Hepburn KW, et al. Case management of older adults in health maintenance organizations. J Am Geriatr Soc. 1995;43(5): $538-542$.

58. Sheaff R, Boaden R, Sargent P, et al. Impacts of case management for frail elderly people: a qualitative study. J Health Serv Res Policy. 2009; 14(2):88-95.

59. MacNeil Vroomen J, Van Mierlo LD, van de Ven PM, et al. Comparing Dutch case management care models for people with dementia and their caregivers: the design of the COMPAS study. BMC Health Serv Res. 2012;12:132.

60. Fixsen DL, Naoom SF, Blase KA, Friedman RM, Wallace F. Implementation Research: A Synthesis of the Literature. Tampa, FL, USA: The National Implementation Research Network; 2005.

61. Hutt R, Rosen R, McCauley J. Case-Managing Long-Tem Conditions. What Impact Does it Have in the Treatment of Older People? London, UK: King's Fund; 2004.

62. Meeks J. A social work case management experience in a managed care setting: the need for effective communication. Home Health Care Manag Pract. 2001;13(6):444-451. 


\section{Supplementary material}

\section{Search strategy in Psyclnfo}

I. dementia/or aids dementia complex/or dementia with lewy bodies/or presenile dementia/or semantic dementia/or senile dementia/or vascular dementia/or alzheimer's disease/or cognitive impairment/or corticobasal degeneration/or creutzfeldt jakob syndrome/or melas/or neurodegenerative diseases/or neurofibrillary tangles/or parkinson's disease/or picks disease/or pseudodementia/or senile plaques/(65089)

2. exp Cognitive Impairment/(I7032)

3. ((cognit* adjl disorder?) or (cognit* adj I impairment?)).mp. (266I8)

4. pick?? disease.mp. (407)

5. (dementia? or alzheimer*).mp. (5435I)

6. lewy body.mp. (865)

7. I or 2 or 3 or 4 or 5 or $6(80731)$

8. health care delivery/or case management/or care management/or case coordination/or clinical practice/or "continuum of care"/or evidence based practice/or health care administration/or health care costs/or health care economics/or health care policy/or health care reform/or health care services/or health care utilization/or health service needs/or needs assessment/or outreach programs/or palliative care/or prevention/or private practice/or "quality of care"/or "quality of services"/or treatment/or treatment barriers/or treatment planning/(I39434)

9. $\exp$ therapeutic processes/or exp therapeutic environment/or treatment termination/(48222)

10. 8 or 9 (183098)

II. (model? or intervention? or program? or process or coordinat*).mp. [mp=title, abstract, heading word, table of contents, key concepts, original title, tests and measures] (750405)

12. 10 or II (8467I2)

13. screening/or health screening/or diagnosis/or geriatric assessment/or health promotion/or screening tests/or symptom checklists/(46065)

14. follow*.mp. or exp Followup Studies/(280658)

15. 12 or 13 or 14 (1031166)

16. clinical pathway?.mp. (121)

17. disease management.mp. or exp Disease Management/(3558)

18. exp Teams/or exp Work Teams/(8829)

19. integrated services/or community services/or interdisciplinary treatment approach/or multimodal treatment approach/or social programs/or social services/(21170)

20. 16 or 17 or 18 or $19(33008)$

21. 15 or 20 (1040467)

22. 7 and 21 (36566)

23. limit 22 to (English or French) (35248)

24. exp Primary Health Care/or exp General Practitioners/(I358I)

25. (communit* or home*).mp. [mp=title, abstract, heading word, table of contents, key concepts, original title, tests and measures] (2I5688)

26. (primary adj2 care).mp. [mp=title, abstract, heading word, table of contents, key concepts, original title, tests and measures] (I9850)

27. exp Family Medicine/or exp Family Physicians/(1552)

28. exp Social Workers/or exp Social Casework/or social work*.mp. (23405)

29. 25 and 28 (5640)

30. nurse?.mp. or exp Nurses/(31729)

31. 25 and 30 (6656)

32. occupational therapist?.mp. or exp Occupational Therapists/(2979)

33. 25 and 32 (7I2)

34. exp Physical Therapists/or physiotherapist?.mp. (772)

35. pharmacist?.mp. or exp Pharmacists/(1460)

36. 25 and 35 (526)

37. (physician? and (home? or communit* or general or family)).mp. (I3177)

38. exp Health Personnel/or health professional?.mp. (84756)

39. 25 and 38 (12752)

40. care navigator?.mp. (2)

41. care navigator?.mp. or Professional Referral/(2205)

42. 24 or 25 or 26 or 29 or 31 or 33 or 36 or 37 or 39 or 41 (241605)

43. ((family adjl practi*) or (general adjl practi*)).mp. (I0549)

44. 42 or 43 (244710)

45. 7 and 21 and 44 (6440)

46. limit 45 to ((English or French) and yr=“I995-Current”) (56I4)

Clinical Interventions in Aging

\section{Publish your work in this journal}

Clinical Interventions in Aging is an international, peer-reviewed journal focusing on evidence-based reports on the value or lack thereof of treatments intended to prevent or delay the onset of maladaptive correlates of aging in human beings. This journal is indexed on PubMed Central, MedLine,
CAS, Scopus and the Elsevier Bibliographic databases. The manuscript management system is completely online and includes a very quick and fair peer-review system, which is all easy to use. Visit http://www.dovepress. com/testimonials.php to read real quotes from published authors. 